\title{
環境研究に遅れてやってきた都市社会学 総合環境社会学への貢献と新しいパラダイムの創造
}

\author{
田中重好
}

\section{1 問題の端緒}

2002 年の都市社会学会シンポジウムの席上、長谷川公一は次のような問題提起を行っ た。「都市社会学者は『環境』を都市論の課題として論じることはきわめて稀」[長谷川、

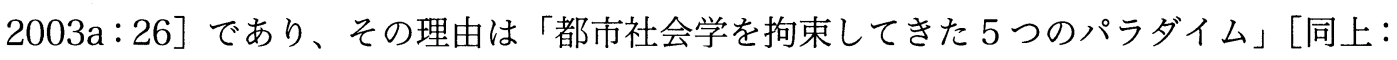
28にによるものである。今後は、こうしたパラダイムを超えた「新しいパラダイム」の もとで、「サステイナブル・シティと地域環境再生」というテーマに取り組むべきだ。

こうした長谷川公一の批判に対しては、昨年度の学会誌上で松本康の反論 [松本、 2003）が述べられている。この提起を引き継いで、2003 年の大会に抏いて、シンポジウ ム「都市と環境——サスイナビリティとコミュニティ—」が行われた。このシンポジ ウムの中でも、森岡清志が、「これまでの都市社会学の研究蓄積のなかには、環境研究に 益する数多くの遺産がある」と反論した。

この小論では、長谷川公一から提起された都市社会学への批判と反批判を手がかりに、 ひろいコンテクストから、都市と環境の問題を議論し、今後の都市社会学から環境研究を 進めてゆく方向性を検討したい。

\section{2 都市と環境}

まず、基本的な都市と環境との関係を見ておきたい。

都市という社会的存在は、その出発点から、それ自体では自立できない存在であった。 藤田弘夫 [藤田、1991］がいうょうに、都市はいつの時代においても、大きな人口規模 を抱えながら、「食糧の自立」がまったくできない存在であった。古代から、都市で消費 される食糧は遠方から運ばれてきた。しかも、食糧自給能力をもたない都市が、社会全体 が食糧不足で飢えていた時でも、「都市は飢えなかった」。また、都市人口すら、都市内で は再生産されずに、つねに、非都市地域から供給されることで、維持されてきた。食糧だ けにとどまらず、都市的生活が「豊かで、快適に」過ごせるのは、周囲からのエネルギー 
の供給を仰ぐことができたからであった。

このように、都市は、都市それ自体では、社会的にサステイナブルな存在ではなかった。 さらに、近代になると、膨張するように肥大化した都市は、社会全体の環境面でのサステ イナビリティを突き崩すまでになってきた。

しかし、そのことに気づき、社会問題として取り上げられるようになってきたのは、ご く最近のことである。それは、ローマクラブの地球環境全体のサステイナビリティへの 警告 [D. H.メドウズほか、1972=1972］とともに始まった。従来、「文化全体が、限界 に従って生存することを学ぶよりも、むしろ限界と戦うという原則をもって進歩してきた ……しかし、地球の限界と人類の活動の間の相対的な関係は変化しつつある……にもかか わらず人類は、地球の限界に近づいているということをまだ理解していないように思われ る」[D. L.メドウズほか、1972=1972: 133-134]。

都市の側から見ると、都市問題の解決を求めて、都市の外側へ、さらに海外へ、食糧、 居住空間やレジャーのための空間、原材料、エネルギー、安価な製品と労働力・サービス を求めていった。そのため、「生活の豊かさ・快適さと環境とのジレンマ」が存在したに もかかわらず、都市生活者から見ると、このジレンマを成立させる都市という場の外枠が 絶えず拡大しているために、ジレンマがジレンマとして受け取られなかった。

日本だけに限ってみても、環境破壊がたとえば鉱山周辺などのように非都市地域に限定 されていた段階から、水俣市や四日市市などの地方都市に集中的に発現し、さらに、大気 污染や都市型気候などのように大都市へと及んできた。農産漁村から地方都市、さらに、 大都市へと環境問題が発現してきた。それに従って、大都市の電力は遠方の原子力発電所 の立地に支えられ、大都市で大量に消費される紙は第三世界の熱帯の原始林の乱伐によっ て可能になっていることが、次第に都市生活者に「見えてきた」。

しかし、そのことが直ちに、都市という存在そのものや都市的生活様式のあり方への、 根本的な問い直しにつながってこなかった。また、都市全体の環境管理、さらに成長その ものの管理へと議論が進んでこなかった。近年、ようやく、都市成長管理、コンパクトシ ティ、サステイナブルな都市のあり方が議論されるようになってきた。

現在の都市のあり方が、社会全体の環境破壊を引き起こしている。かつて、文明の最先 端であった都市はいまや、環境破壊の最先端を走っている。そのため、都市それ自体が環 境面でサステイナビリティを回復することなしには、社会全体の環境を回復することはな い。こうした意味で、環境問題のもっとも中心的なアリーナは都市社会であり、都市社会 学に課せられている任務は重大である。都市社会学者にとって、環境問題となんらかの接 点をもつことが求められている。

\section{3 「前衛の環境研究」と「後衛の環境研究」}


それにもかかわらず、都市社会学では環境問題に関する研究が従来少なかったというこ とが、長谷川公一の第一の指摘であった。この点は、事実として認めよう。

だが、すべての都市社会学者が環境問題を直接研究しなければならないということには ならない。ただし、「環境問題のもっとも中心的なアリーナは都市社会である」という事 実と関連して、環境問題となんらかの接点をもつことを求められている。では、「都市社 会学が環境問題と接点をもつ」ということはどういうことを意味するのだろうか。

それを考える際、二つの局面に分けて、議論してゆかなければならない。それは、都市 社会学が直接に環境を研究することと、間接的に環境研究につながる研究をすることに分 けて考える必要がある。

かつて、災害研究に対して社会学がどう関われるのかという問題について、私は次のよ うに議論した。

災害研究は「前衛の災害研究」と「後衛の災害研究」とに分けることができる。「災害 研究というと、これまで、ここでいう『前衛の災害研究』だけが注目されてきた。すなわ ち、被災地における、発災以降の社会的被害、人間行動、生活再建、緊急時の社会的対応、 災害復旧過程などが研究の対象とされてきた。しかし、災害研究にはもう一つの局面があ る。それが『後衛の災害研究』である。それは、『災害を、被災の場面に限定させず、発 災を中心とした短期に限定せず、さらに、災害を人々の日常生活の全体性のなかで研究す る』[田中、1999a：99］ものである」[田中、2001：144]。

この災害研究における「前衛の研究」と「後衛の研究」との区分と同じことが、環境研 究についてもいえる。そして、長谷川が提起した問題も、この二つの側面の研究を注意深 く分けながら、検討しなくてはならない。

\section{4 前衛の環境研究}

前衛の環境研究に関しては、詳しい説明を要しないであろう。シンポジウム当日、中澤 秀雄、原田利恵、丸山定巳各氏の発表は、直接、環境問題を取り上げた研究である。

一般的に考えても、都市社会学からの前衛の環境研究には、環境破壊が集中的に発現し ている都市の研究、あるいはその反対に、サステイナブルな努力を積極的にしている都市 の研究が考えられる。こうした研究対象を設定した上で、ではなぜ、こうした環境の悪化 をもたらしたのか、その社会的メカニズム、さらに、環境破壊にともなって発生する社会 的現象（差別、病苦と貧困など）、環境問題を解決する社会的プロセス（社会運動、行政、 企業の役割)、という研究テーマがある。環境都市に関しても、なぜその都市で、環境政 策は成功したのか（あるいは、失敗したのか）、その社会的原因やメカニズムが問題となる。 こうした研究はともに、都市環境の改善や環境政策の立案に役立つ研究ともなる。

ただし、都市社会学にとって、こうした前衛の環境研究において、つねに問題となるの 
は次の点である。環境問題は発生の原因も㷌結も、都市というバンウダリーを超えて拡が っている。そうしたなか、都市あるいはコミュニティという社会的ユニットを設定して、 環境を考えることにどんな意味があるのか。より政策的な言い方をすれば、どの地域的な ユニットで、どういった問題解決の可能性を検討するのか、という問題である。

こうした問題設定の背景には、「規模の経済」に象徵される巨大化、広域化によって効 率性を達成してきた従来の方向性から、たとえば、循環型都市の実現という問題設定に現 れているように、もう一度、小さいユニットへ問題を「埋め戻す」ことが必要であるとい う認識がある。たとえば、持続可能な社会システムの構築のためには、「まず物の循環系 を回復しなければならないが…...この事の前提として農業と工業のバランスを取り戻し、 適正な規模で『農業的要素と都市的要素とが接近・モザイク化』された地域ユニットをつ くらねばならない」[内藤、1998:208］と指摘されている。こうした指摘を踏まえた上で、 では、近隣社会からグローバルな社会まで多重的に連続する社会的レベルの、どのレベル・ 規模で、いかなる程度、物質循環を完結させるのか、が問われているのである。

\section{5 後衛の環境研究}

\section{1 パラダイムの持つ両義性}

しかし、都市社会学が環境研究に関わるのは、直接に環境をテーマとする局面だけでは ない。前衛の環境研究を成り立たしめる基盤となる研究が必要となる。

長谷川公一は、従来の都市社会学が環境問題や環境政策にあまり注意を向けなかったの は、「人間中心主義パラダイム」「集団・社会関係中心主義パラダイム」「都市の自己完 結型パラダイム」「都市的生活様式論パラダイム」「都市 - 農村パラダイム」の 5 つのパ ラダイムがあるからではないか、と指摘している [長谷川、2003a：28］。

この長谷川公一の指摘は、両義的である。なぜ両義的かといえば、一方で、たしかに都 市社会学がこうしたパラダイムを相対化し、更新しなければならないと同時に、他方では、 このパラダイムの遺産を生かしてゆかなければならないからである。

\section{2 都市的生活様式パラダイム再考}

パラダイムの相対化、更新に関して、日本の都市社会学にとってもっとも特徵的な都市 的生活様式論パラダイムについて、検討しておこう。都市的生活様式とは「生活の社会化」 とも呼ばれる。

都市化によって、「自家処理から共同処理へ、それも素人の相互扶助的な共同処理から 専門機関による専門処理システムへ」と移行してゆく［倉沢、1977:35]。そのことを倉 沢進は、「生活の社会化」と呼んだ。すなわち、「生活の社会化」とは、行政サービスと商 業サービスからなる「専業的な問題処理システム」への依存を強めていく過程である。た 
だし、専門機関のサービスの比重が高まり、都市的公共施設が高度化・複雑化・巨大化し てきた現在、改めて、「巨大な施設体系をふくんだ専門的処理システムの中に相互扶助シ ステムをサブシステムとして組みこむことができるか」が問われている、ということを倉 沢進は見逃してはいない。

倉沢進の「生活の社会化」論を森岡清志は次のように整理している。「都市生活とは、 みえざる共同性、不透明な共同性によって特色づけられる社会的共同的生活である。この 不透明な共同性は、諸個人の生活が相互に媒介的な連関によって結ばれる結果として生ず る共同性である」[森岡、1990：288]。専門的機関による生活問題の処理がおこなわれ る都市において、人々は、「生活が直接的共同性のもとに埋没し、個的生活を自立的単位 として析出することにほとんど意味がないような個人」とは異なり、「サービス選択の主体、 私的自由の実践主体」[同上：291］となる。

生活の社会化論的な観点からすれば、この私的自由・自治を基本とした個人の都市的生 活様式と、専門的処理機関による生活問題の処理方式とが組み合わされているのが都市社 会である、ということになる。

しかし、生活の社会論のもつ楽観的傾向に対しては、さまざまな批判が投げかけられて いる。「近代以降の産業社会によって切断され、断絶させられてきたアップストリームと ダウンストリームをどのように再統合し、循環的なシステムとして再編成するのか、とい う課題に、私たちは直面している」[長谷川、2003b：28］と考光る長谷川公一は、生活 の社会化論＝都市的生活様式論について次のように批判する。「都市的生活様式は、倉沢 進（1977）以来、『専門処理システムによる共同処理を原則とする共同生活の営み方』[森 岡、1993：1094] であるとされるが、倉沢らに代表される主流派の都市社会学は、専門 処理システムへの依存を自明視し、それのもつ問題性、ダウンストリーム問題の深刻さを 射程の外においてきたといえる。都市的生活様式論からは、循環や共生を重視するエコロ ジカルなライフスタイルを評価する視点はうまれがたい」[同上：28]。ただし、専門的 処理システムへの依存にともない、さまざまな問題が発生することを指摘した論文 [園田、 1980 ；田中、1992] がなかったわけではない。

このパラダイムを相対化するために、まず、時代的な背景を検討しなければならない。生 活の社会化」論は、戦後日本の高度経済成長の過程で一般化した都市的生活様式を定式化 したものである。しかも、私的自治と専門的処理を組み合わせれば、問題は解決できると、 人々が信じていた時代の産物である。こうした楽観的な立場をそのまま生活の社会化論は 受け継いでいる。このような時代的な限定をもっている。

1990 年代以降、私的自治と専門的処理の中間に「共」を見いだし、さらに、都市生活 者の間に「ダウンストリームへのまなざし」をもつ人々が増えてきている。その点で、都 市的生活様式が流動化しながら、多元化している。一方の極には依然として、倉沢進が描 いた都市的生活様式をもって暮らしている人々があり、その反対の極には、この生活様式 
から抜け出そうと努力し、「もう一つの生活のあり方」を確立しょうと努力している人々 がある。

ただし、都市社会学において、こうした、ポスト「生活の社会化」論の変化を十分定式 化しえていないことも確かである。私見では、1990年代以降、地域への共同性の埋め戻し」 [田中、2004］が始まっており、それにともなって、新しい生活様式を模索する動きも加 速化していると考えている。

\section{3 パラダイムの遺産継承}

以上の意味で、かつての都市的生活様式パラダイムは更新をもとめられているが、都市 社会学が都市的生活様式を研究することの必要性は、依然として失われてはいない。この 生活の社会化論は、都市生活者がなぜ環境問題を棚上げして暮らしてきたかを説明する力 をもっている。

長谷川公一が指摘する他のパラダイムについても同様なことが指摘できる。都市社会学 は、都市における集団や社会関係を解明することに力点を置いてきたことは確かである。 また、都市社会学として、都市を相対的に自己完結的なものとして論じている」[長谷川、 2003a：29]ことも確かである。さらに、「『都市的なるもの』を『農村的なるもの』との 対比のなかで考察し、論じてきた」[同上：30］ことも確かである。長谷川も指摘するよ うに、こうした点は「都市社会学者にアイデンティティと存在理由を与えてきた」[同上: 30] のである。

むしろ、都市社会学内部から問題とすべきなのは、こうしたパラダイムに立脚して行わ れてきた研究の蓄積を生かして、どう環境研究につなげてゆけるのか、である。

具体的には、都市の集団やネットワークのあり方が、なぜ環境問題を自覚化することに 役立つ（あるいは、役立たない）のか、また、それが問題解決に役立つ（あるいは、役立 たない）のか、を明らかにすることが求められているのであって、都市社会学的な研究で 関係や集団の研究を放棄することが求められているわけではない。もちろん、関係や集団 に関する研究が、自己目的化し、自閉的なものになってしまうことは論外である。

ぞうように、相対的に自己完結的な都市が、資源・エネルギー循環の面からどう可能な のか、農村とは異なる都市のなかで持続可能な生活がどう成り立つのかを、検討する必要 がある。

こうした意味で、パラダイムそれ自体が悪いのではない。むしろ、このパラダイムに「正 しく」立脚しながら、環境研究へと射程を伸ばす、あるいは、伸ばす可能性をもつ研究を 進めることが求められているのである。

長谷川公一の指摘が両義的であるといったのは、生活様式や社会的ネットワーク・集団 という視点から環境という次元へと連結する力があるかどうかによって、各パラダイムは プラスかマイナス、正反対の価值をもつことになるからである。 


\section{6 「都市と環境」をめぐるもう一つの問題：都市社会学と政策研究}

都市と環境とを考えるとき、もう一つの問題が残っている。この問題も、昨年度のシン ポジウム「隣接領域からの批判と期待」以来、引き継いだ問題である。

そのシンポジウムの際、農村社会学の立場から徳野貞雄は、都市・農村社会学の「共通 課題」として、「政策科学としての連携的な対応」を求め、「『この国のくらし』について、 政策提言的な研究を共同で深化させていく」[徳野、2003:21] 必要を指摘した。それに 関連して、松本康からは、「日本において、社会学者が政策提言に関与する場合には、そ れは学問的営為の外部における活動であるとして扱われてきた」。そのため、「外部におい て規範的議論に関与しながら、学会内部においては記述的議論にとどめるという『二重帳 簿』」[松本、2003: 70] が存在するという。

都市と環境を研究してゆく場合、環境面でのリスクが深化している現在、政策議論をい つまでも都市社会学的な研究の外側においておくことは適切ではない。「二重帳簿」は都 市社会学にとって健全なことではないし、その可能性を殺いでしまうものである。しかし ながら、同時に、すべての研究が、政策研究となる必要もない。むしろ、ここで我々が考 えるべきは、政策研究とどう連接できるのかという点である。

政策研究とは、現実的な問題に対して答えをだす、いわゆる「役にたつ」研究である。 もう少し厳密にいえば、その研究が政策研究であるためには、「誰が、いつ、どういった 目標の下に、どういった手段をもって、何を達成すべきなのか」が論じられていなければ ならない。そうした意味で、都市社会学に限らず、社会学の政策研究は少ない。

この問題を考える際にも、災害研究と同じことが必要となる。

災害研究は、「狭義の災害研究」と「防災研究」に分けて考えることが必要である。「防 災という目的を合理的に達成する方法・手段を明らかにする研究を防災研究と呼び、防災 を一義的な目的とはしていない災害時の人間や社会の研究を災害研究と呼ぶ。……防災研 究は、防災性を高める要因を摘出し、その要因をどう変化させていったら防災に役立つか を追求する。防災研究は工学的な、あるいは応用的な『役に立つ』研究である。防災研究 においては、具体的に、誰が、何をすればいいのか』について答えてゆくことが求められる。 ……これと対照的に、狭義の災害研究は防災のための研究を一義的にはめざしていない。 むしろ、それまで『見えなかった』局面が災害という場面ではじめて見えてくることに着 目し、災害発生時の社会や人間、都市を研究するものである」[田中、2001：142-143]。 ここでは、防災研究は政策研究であり、狭義の災害研究は非政策研究である。

環境研究についても、前衛の研究と後衛の研究、政策研究と非政策研究を組み合わせる と、4つの領域に分けられる（図 1 参照）。

公害被害者の救済に関する研究を例に各領域のテーマをあげてみると、前衛の政策研究 


\begin{tabular}{|c|c|c|}
\hline & 政策的研究 & 非政策的研究 \\
\hline 前衛の研究 & 前衛の政策研究 & 前衛の非政策研究 \\
\hline 後衛の研究 & 後衛の政策研究 & 後衛の非政策研究 \\
\hline
\end{tabular}

図 1 環境研究の諸次元

\begin{tabular}{|l|c|c|}
\hline & 政策的研究 & 非政策的研究 \\
\hline 前衛の研究 & \\
\hline 後衛の研究 & 環境社会学 \\
\hline 都市 & 社会学 \\
\hline
\end{tabular}

図2 総合環境社会学へ

の課題は、「公害被害者の救済策をどう立案するか」となる。このためには、「公害被害者 がどの階層に集中しているのか」ということを明らかにする必要がある（前衛の非政策研 究)。この問題は「都市の階層構造の究明」（後衛の非政策研究）と、「特定階層への公的 支援のあり方をどうするか」（後衛の政策研究）という問題に関連している。

このように都市社会学は、前衛の政策研究そのものに関与するだけではなく、後衛の、 あるいは非政策的局面の研究を含んでいる。ここにおいても、各自の研究が、この図上の どこに位置づけられ、都市の環境研究と「いかなる接点をもっているか」に自覚的である ことが求められている。

日本の環境問題が「公害問題」という加害 - 被害関係の明確な問題として歴史的に展開 してきたため、環境社会学も運動論を中心に研究が進められてきた。それは、環境への制 度的な対応が後手後手にまわった日本の特徵を反映したものでもある。

それに対して、「遅れてやってきた」都市社会学は、環境社会学が中心となって取り上 げてきた社会運動の外側で、しかも、環境問題を規定する強い力をもつ領域に注目して研 究する必要がある (図 2 参照)。そして、政策的 - 非政策的、前衛 - 後衛の環境研究が総 合的に蓄積されてゆくとき、環境社会学に都市社会学を含めた連字符社会学が協働して「総 合環境社会学」といったものが完成するであろう。

こうした役割を果たしてゆくためには、現在の都市社会学において不足している議論は、 都市のガバナンスと自治の問題である。都市社会学は、これまで、都市を「自然の産物」 とみなす傾向が強く、都市を「人々が造ってゆく場」と考えることが少なかった［田中、 
1999b : 197]。しかし、ガバナンスと自治に関する議論なしには、サステイナブルな都 市創造の問題を論ずることはできない。その意味で、都市と環境との研究において、焦眉 の課題は「都市のガバナンスと自治」のパラダイムの構築なのである。

\section{文献リスト}

長谷川公一．2003a「環境社会学と都市社会学とのあいだ」日本都市社会学会編『日本都市社会学 会年報 21 』

長谷川公一. 2003b『環境運動と新しい公共圈』有斐閣

藤田弘夫. 1991『都市と権力——飢餓と飽食の歴史社会学—』創文社

倉沢進．1977「都市的生活様式論序説」磯村英一編『現代都市の社会学』鹿島出版

松本康.2003「都市社会学の遷移と伝統」日本都市社会学会編『日本都市社会学会年報 21 』

D.H.メドウズほか. 1972=1972『成長の限界』ダイヤモンド社

内藤正明. 1998「持続可能な社会システムの構築」『岩波講座 地球環境学 10 持続可能な社会シ ステム』岩波書店

森岡清志. 1990 「都市生活の共同性と個別性」倉沢進・秋元律郎編『町内会と地域集団』ミネルヴ ア書房

森岡清志. 1993 「都市的生活様式」森岡清美・塩原勉・本間康平編『新社会学辞典』有斐閣

園部雅久. 1980 「街づくり運動の変容と適正技術論」『社会学論考』1 号

田中重好。1992「コミュニティの復権は可能か」金子勇・園部雅久『都市社会学のフロンティア 3 変動・居住・計画』日本評論社

田中重好. 1999a「後衛の災害研究」弘前大学人文学部『人文社会論叢 社会科学編』2 号

田中重好．1999b「都市計画とまちづくり」藤田弘夫・吉原直樹編『都市社会学』有斐閣

田中重好．2001「阪神淡路大震災から都市研究へ」金子勇・森岡清志編『都市化とコミュニティの 社会学』ミネルヴァ書房

田中重好. 2004「戦後日本の共同性の変遷」慶應義塾大学法学研究会編『法学研究』第 77 巻 1 号 徳野貞雄。2003「現代の “ムラ”と“農”から見た都市社会学」日本都市社会学会編『日本都市社 会学会年報 21 』

(たなかしげょし/名古屋大学大学院環境学研究科教授) 